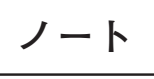

[木材学会誌Ｖol. 53, No. 3, p. 149-156 (2007)]

\title{
園芸療法用木製レイズドベッドのエルゴデザイン 高齢者の作業しやすい高さと奥行き*1
}

\author{
大釜敏正 $* 2$, 野田勝二 $* 2$, 桜庭 俊*3, 北条雅章 $* 2$, 小宮山政敏 $* 2$, \\ 上田善弘 $* 4$, 赤沼智子 $* 5$, 寺内文雄 $* 6$, 池上文雄 $* 2$
}

\section{Ergonomic Design of Wood-Based Raised Bed for Horticultural Therapy Comfortable height and reach distance for elderly persons*1}

\author{
Toshimasa OHgama*2, Katsuji NodA*2, Shun SAKURABA*3, Masaaki HoHjo*2, \\ Masatoshi KomiYama ${ }^{* 2}$, Yoshihiro UedA *4, Tomoko AkAnUma*5, \\ Fumio TERAUCHI ${ }^{* 6}$ and Fumio IKEGAMI $* 2$
}

\begin{abstract}
The purpose of this study was to obtain the basic data required to design a raised bed for plants suitable for the horticultural therapy in which able-bodied or frail elderly persons can perform gardening in a relaxed standing posture. Comfortable heights of working surface and reach distances were measured in a bimanual transplant task. The results obtained were as follows : (1) Among able-bodied elders, comfortable heights selected by most males were 85 and $90 \mathrm{~cm}$, while those of females were 75 and $80 \mathrm{~cm}$. The height of the raised bed suitable for standing work could be roughly estimated as $20 \mathrm{~cm}$ below elbow height. Comfortable reach distance ranged from 20 to $40 \mathrm{~cm}$ both in males and females. (2) In frail elders, $70 \mathrm{~cm}$ was selected as the comfortable height. However, it was found by interviews that sensuously there was no great difference between $70 \mathrm{~cm}$ and $80 \mathrm{~cm}$. The range of the comfortable reach distance was from $10 \mathrm{~cm}$ to $45 \mathrm{~cm}$. (3) Taking together, the range from $10 \mathrm{~cm}$ to $40 \mathrm{~cm}$ could be a desirable reach distance for both kinds of elders. (4) Many elders complained of possible backaches after the transplant task using lower raised beds. In addition, elders with disabilities also complained of light fatigue around their knees.
\end{abstract}

Keywords: $\quad$ horticultural therapy, raised bed, elder, standing posture.

本研究の目的は, 健常高齢者および障害を有する高齢者が楽な立位姿勢で園芸作業を行うこと ができる園芸療法用のレイズドベッドの設計に必要な基礎的なデータを求めることである。作業 しやすい高さと楽に手が届く距離を，両手による植物の植え付け作業から求めた。得られた結果 は以下のとおりである。（1）健常高齢者の作業しやすい高さは，男性では8 $8 \mathrm{~cm}$ および $90 \mathrm{cm，女}$ 性では75 cm および $80 \mathrm{~cm}$ であった。作業しやすいおおよその高さは, 肘頭下縁高から $20 \mathrm{~cm}$ 低い 高さが目安となる。また，楽に手が届く距離は男女ともに $20 \mathrm{~cm} \sim 40 \mathrm{~cm}$ の範囲であった。(2) 障 害を有する高齢者の場合では，作業しやすい高さは70 cm が多かったが， $80 \mathrm{~cm}$ のもとの間に 感覚的には大差のないことが聞き取り調査から分かった。楽に手が届く距離は $10 \mathrm{~cm} \sim 45 \mathrm{~cm}$ の範 囲であった。（3）したがって，健常高齢者および障害を有する高齢者の両者が作業しやすい奥行

*1 Received July 19, 2006 ; accepted October 10, 2006.

*2 千葉大学環境健康フィールド科学センター Center for Environment, Health and Field Sciences, Chiba University, Kashiwa 277-0882

*3 島田建設 Shimada Construction Incorporation, Narita 286-0823

*4 岐阜県立国際園芸アカデミー Gifu International Academy of Horticulture, Kani 509-0251

*5 千葉大学看護学部 School of Nursing, Chiba University, Chiba 260-8672

*6 千葉大学工学部 Faculty of Engineering, Chiba University, Chiba 263-8522 
きは $10 \mathrm{~cm} \sim 40 \mathrm{~cm}$ とするのが望ましい。(4)多くの高齢者が低いレイズドベッドでの作業後に腰 痛の可能性があると訴えた。障害のある高齢者は膝にも軽度の疲労があると訴えた。

\section{1. はじめに}

高齢社会となり，高齢者の健康回復・維持・増進 に代替医療（補助的療法）としての園芸療法が注目 されつつある。園芸療法は, 植物そのものや植物が 育つ環境から私たちが受ける刺激や，植物に関連す る様々な活動を, 精神機能や感覚運動機能の維持・ 回復，生活の質（Quality of Life：QOL）の向上に用 いるリハビリテーション技法の一つである1)。また， 近年のエコロジー時代にあっては, 障害者や高齢者 が社会環境と共存していくエコロジカル・アプロー チとしての環境療法, 芸術療法の視点が浮上してき ている。これらのエコロジカル・アプローチの中で, 近年急速に話題を集めている技法の一つが園芸療法 でもある2)。

園芸療法の効果を高めるには，安全で安心して園 芸作業が行える施設・設備のもとで, 療法対象者の 興味や関心, 経験, 心身の機能, さらには季節や気 象条件, 作業内容・時間などの基本的な事項が考慮 された園芸療法プログラムが求められる。

このような観点から, 千葉大学環境健康都市園芸 フィールド科学教育研究センターでは, (1)立位およ び座位姿勢で足腰に負担が少なく楽に園芸作業が行 える木製のレイズドベッド（raised bed：作業面と なる土面を高くした園芸用設備）の設計・製作に必 要な基礎的なデー夕を得るための実験と, (2)各種の 園芸作業が気分・感情など人の心理的および精神的 側面にどのような影響を及ぼすか，また，ストレス がどれくらい軽減されるか, 等について実験を進め ている。

ここでは，前者について，健常高齢者とデイサー ビス施設を利用している何らかの障害を有している 高齢者を対象に，立位姿勢で行った花の植え付け作 業から得られた結果を報告する。なお, 本報告では, レイズドベッドに被験者が正対して両手で作業を行 うとき, 足腰に負担がなく楽な姿勢で作業が行える 作業面の高さと奥行きの 2 項目に焦点を絞ることに した。

\section{2. 高齢者の身体機能特性とレイズドベッド}

園芸作業において，高齢者の動作に影響を及ぼす と考えられる身体機能特性を整理すると, (1)視力・ 聴力・皮膚感覚の感覚機能㧍よび平衡感覚の低下が 著しい, (2)手や腕の筋力, 背筋などに比べて脚力の
低下が大きい，(3)脊柱の前屈や側屈に比べて肩関節 の柔軟性の低下が目立つ, (4)動作調節能力（速度に 関係した運動機能）の低下が著しい，5)75歳を境に 平地歩行能力が大幅に低下する, (6)身長や胸囲等の 身体部位寸法は加齢に伴い減少する，(7)高齢になる ほど有病率が高く，筋骨格系および結合組織の疾患 は循環系の疾患に次いで多い，などを挙げることが できる゙。

このような身体特性を有する高齢者にとって，地 面にかがみ込む園芸作業は, 若壮年層に比べて腰部 や脚部への負荷がより大きく作用すると考えられる ことから，作業面となる土面を高くとることによっ て, 足腰に負担の少ない楽な姿勢で作業が行えるレ イズドベッドを創出する必要がある。

また，車いすに頼らざるを得ない障害を有する高 齢者も多いことから，レイズドベッドに正対して作 業が行えるよう, 車いす利用者の脚部がベッドの下 部に入る空間を設ける工夫も視野に入れておく必要 がある。

\section{3. 実験 1 健常高齢者}

\section{1 実験方法}

3.1.1 実験用レイズドベッド

実験用のレイズドベッドは，丈夫な構造を有する こと, 製作工程数が少なく組立作業が容易であるこ と, 安価であること, 作業域が大きいこと, 座位姿 勢でも使用できること，などを考慮に入れ，Fig. 1 のような形状と寸法を有するものを製作した。すな わち, 図に示すように, 市販のツーバイフォー, ワ ンバイフォーおよびコンクリートパネルの各材料を 用い, ベッドとなる $\mathrm{a}$ の高さを $19 \mathrm{~cm}$ に固定し, 支 持台の高さ $\mathrm{b}$ を変化させることにより, 全体として の高さが $60 \mathrm{~cm}$ から $90 \mathrm{~cm}$ の範囲で $5 \mathrm{~cm}$ 刻みとなる 7 種類を製作した。部材の接合には市販のスクリュ 一釷およびボルトを用いた。レイズドベッド内の土 の高さは上面から $5 \mathrm{~cm}$ 下げた位置とした。したが って, 実際の作業面の高さは, 実験に供したレイズ ドベッドの高さより $5 \mathrm{~cm}$ 低いことになる。しかし， 設備の設計という観点からは, 作業台の高さを基準 にとった方が取り扱いやすい。本論文において示す 高さは, Fig. 1 に示したレイズドベッドの高さであ る。

なお，材料に木材を使用し，上記のような仕様に したのは, 人の感性との高い親和性に加えて, レイ 


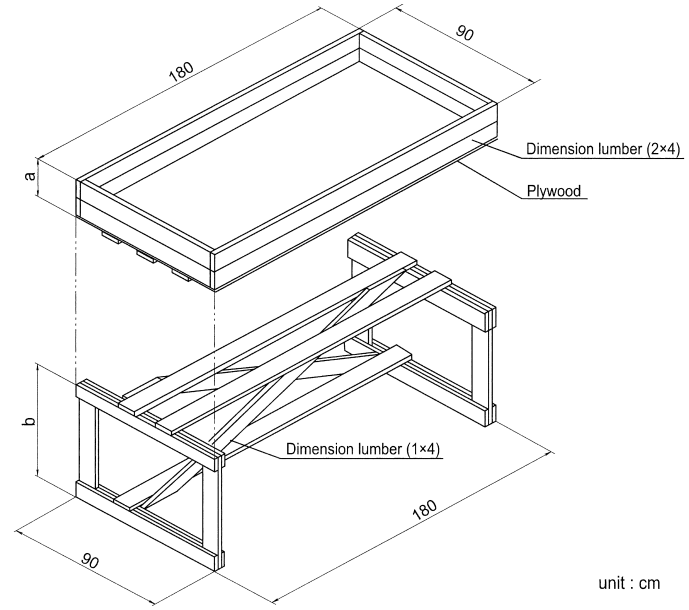

Fig. 1. Schematic diagram of raised bed.

Height of raised bed a $(19 \mathrm{~cm})+\mathrm{b}: 60 \mathrm{~cm}, 65 \mathrm{~cm}$, $70 \mathrm{~cm}, 75 \mathrm{~cm}, 80 \mathrm{~cm}, 85 \mathrm{~cm}$ and $90 \mathrm{~cm}$.

ズドベッドの製作そのものが園芸療法プログラムの 一要素とみなすことができると考えたからである。

3.1 .2 測定内容の教示

実験に先立ち被験者に次のような説明をした。

「この実験は，花の苗の植え付けなど，両手を使っ た園芸作業をするときに，どのくらいの高さが作業 しやすいか, どのくらいまで手が届くか, どのくら いの高さになると作業がしにくくなるかについて調 べるためのものです。測定した結果は, 当センター 内に設置される園芸療法庭園の花壇などの設計に使 います。これから高さの異なる作業台で，実際にパ ンジーの植え付けを行っていただきます。台の高さ が，高すぎたり，低すぎたりして作業がやりにくい
ときは，無理をしないで申し出て下さい。」

3.1.3 実験手順

実験はつぎのような手順で行った。

(1)被験者にレイズドベッド前縁中央に立って試行作 業を行ってもらい, 足の位置を決める。(2)パンジー の植え付け作業を行ってもらい, 姿勢の変化等, ビ デオ撮影する。また，膝を曲げる，背伸びをするな ど特徴的な変化があればメモをとる。(3)上記作業は, 足腰に負担が少なく楽にできる場合と, 無理のない 範囲で努力すればできる場合について行い, 各々に ついてレイズドベッド前縁からパンジーの苗中央ま での距離を測定する。(4)作業が仮に10分〜15分続く としたら，身体のどの部分に負担がかかると予想さ れるかについて身体を模した概略図に記入してもら う（あるいは聞き取る）。(5) (1)（4)の計測を，まず $60 \mathrm{~cm}, 70 \mathrm{~cm}, 80 \mathrm{~cm}, 90 \mathrm{~cm}$ の 4 種のレイズドベッ ドで行う。(6) 4 種類のレイズドベッドの中でどの高 さが作業しやすかったかを聞き取る。(7)選択された レイズドベッドより $5 \mathrm{~cm}$ 高いものおよび $5 \mathrm{~cm}$ 低い ものにおいて同様の作業を行い, 6 で選択されたレ イズドベッドを含む 2 あるいは 3 種類の中で最も作 業しやすいものを聞き取る。8実験全体を通して気 づいたこと等, 被験者および実験補助者から参考に なると思われる情報を収集する。

なお，上述したビデオ撮影は，被験者の側面全身 が写るように， $5 \mathrm{~m}$ 離れた位置に $90 \mathrm{~cm}$ の高さで固 定した DVD ビデオカメラ (Panasonic VDR-M70K-S) を用いて行った。

被験者は, 男性 9 名, 女性 8 名の計 17 名で, 身体 特性等は Table 1 のとおりである。

Table 1. Body characteristics of the anthropometry subjects.

\begin{tabular}{|c|c|c|c|c|c|c|c|c|}
\hline \multicolumn{9}{|c|}{ Able-bodied elderly } \\
\hline & \multicolumn{4}{|c|}{ male $(n=9)$} & \multicolumn{4}{|c|}{ female $(n=7)$} \\
\hline & $\begin{array}{c}\text { Stature } \\
(\mathrm{cm})\end{array}$ & $\begin{array}{l}\text { Weight } \\
\text { (kg) }\end{array}$ & $\begin{array}{l}\text { Elbow height } \\
(\mathrm{cm})\end{array}$ & $\begin{array}{l}\text { Age } \\
\text { (year) }\end{array}$ & $\begin{array}{c}\text { Stature } \\
(\mathrm{cm})\end{array}$ & $\begin{array}{l}\text { Weight } \\
\text { (kg) }\end{array}$ & $\begin{array}{l}\text { Elbow height } \\
(\mathrm{cm})\end{array}$ & $\begin{array}{l}\text { Age } \\
\text { (year) }\end{array}$ \\
\hline Average & 164.9 & 63.1 & 101 & 68.3 & 151.3 & 53.5 & 94 & 66.3 \\
\hline Range & $160-172$ & $52-73$ & $95-106$ & $61-81$ & $145^{-156}$ & $43-59$ & $85-100$ & $59-70$ \\
\hline
\end{tabular}

Elderly with disabilities (health services facilities for the elderly)

\begin{tabular}{lcccc}
\hline & \multicolumn{4}{c}{ Subject $($ female = 11) } \\
\cline { 2 - 5 } & $\begin{array}{c}\text { Stature } \\
(\mathrm{cm})\end{array}$ & $\begin{array}{c}\text { Weight } \\
(\mathrm{kg})\end{array}$ & $\begin{array}{c}\text { Elbow height } \\
(\mathrm{cm})\end{array}$ & $\begin{array}{c}\text { Age } \\
(\text { year })\end{array}$ \\
\hline Average & 144 & 48.6 & 86 & 85 \\
Range & $130-158$ & $35-64$ & $68-97$ & $71-97$
\end{tabular}

\begin{tabular}{|c|c|}
\hline Anamnesis & Number \\
\hline Dementia & 4 \\
\hline Femoral fracture* & 2 \\
\hline Knee osteoarthritis* & 3 \\
\hline Heart disease ${ }^{*}$ & 1 \\
\hline Muscle weakness (leg) & 8 \\
\hline $\begin{array}{l}\text { Cerebral infarction } \\
\text { (right hemiplegia) }\end{array}$ & 1 \\
\hline
\end{tabular}

* : repetition 


\subsection{4 腰部椎間板圧迫力の推定}

被験者が楽な姿勢で作業できる高さとして選んだ レイズドベッドでの作業時に腰部に生じている負荷 の程度を評価するため, WEB 上で公開されている ソフト Bless ${ }^{4}$ を用いて腰部椎間板圧迫力（第 5 腰 椎と第 1 仙椎の間の椎間板を圧迫する力 $)^{5)}$ の推定 を行った。入力に必要なデー夕は，Fig. 2 に示した 身長, 体重, 取り扱い物重量, 取り扱い物を動かそ うとする方向, 肘 - 上腕 - 上体 - 膝 - 足首の各屈曲 角の 9 種類である。これらのデー夕は，前節で述べ た方法で撮影したビデオ画像から求めた。また，取 り扱い物重量は移植ごてに土袞の重量を加えた 0.5 $\mathrm{kg}$ を想定した。

\section{2 実験結果}

\section{2 .1 作業しやすい高さ}

Fig. 3 に作業しやすい高さとして選ばれたレイズ ドベッドの頻度分布を示した。図には，作業しやす い高さを $1 つ に$ 絞り込むことができなかった被験者 が，第 2 候補としてあげた高さも含めてある。図中 白抜きで示したように，被験者の多くは， $75 \mathrm{~cm}$, $80 \mathrm{~cm}$ および $85 \mathrm{~cm}$ の高さを選択している。しかし ながら，Table 1 からも明らかなように，男性の身 長が $160 \mathrm{~cm}$ 以上であり，女性のそれが $156 \mathrm{~cm}$ 以下 であることから，身長差に基づく男女間の違いがみ られる。すなわち，男性は $85 \mathrm{~cm}$ および $90 \mathrm{~cm} ， 女$ 女性

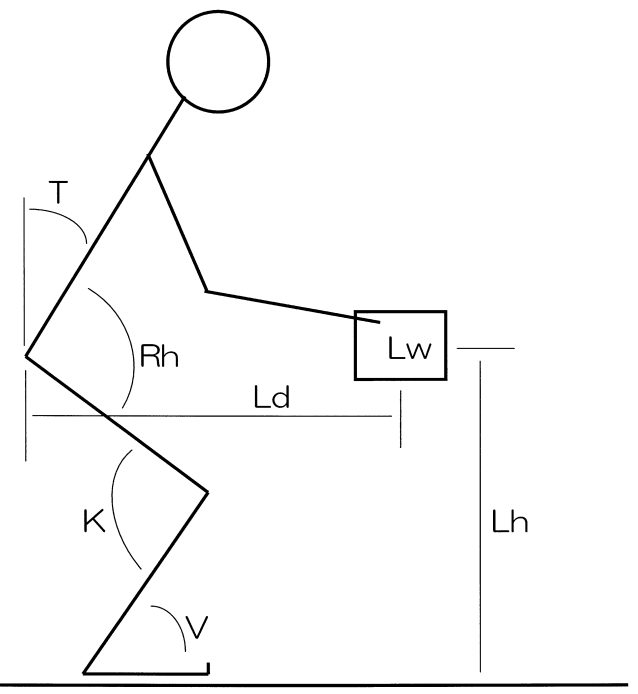

Fig. 2. Parameters of posture to calculate the compression force to lumbar intervertebral disk.

Legend: $\mathrm{T}$ : Trunk flexion angle, Rh : Low back angle, K : Upper leg vertical angle, $\mathrm{V}$ : Lower leg vertical angle, Ld : Horizontal distance to load, Lh : Height of load, Lw : Hand load

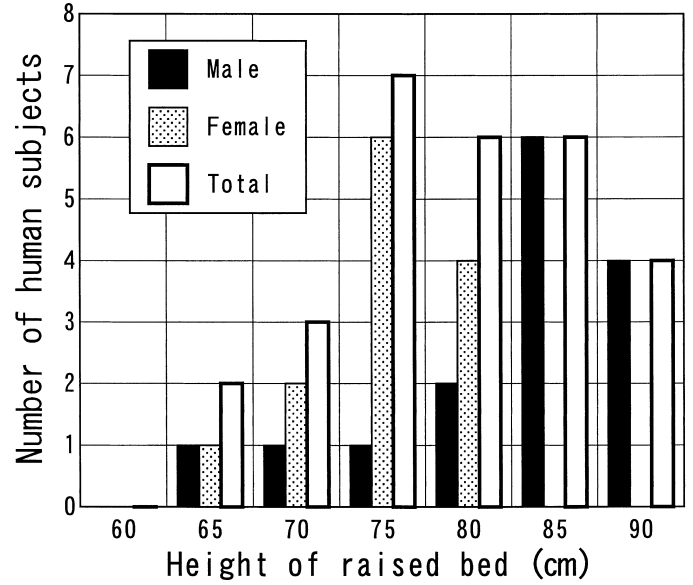

Fig. 3. Distribution of the heights of raised bed judged to be comfortable in standing work posture.

は75 cm および $80 \mathrm{~cm}$ の高さを多く選択している。

\subsection{2 手が届く距離}

Fig. 4 に，全被験者について，足腰に負担が少な く楽に手が届く距離（黒塗りの記号）および無理の ない範囲で努力すれば手が届く距離 (白抜きの記号) と身長の関係を示す。両関係とも有意な正の相関関 係が認められた。相関係数は，それぞれ0.50および 0.32であった。

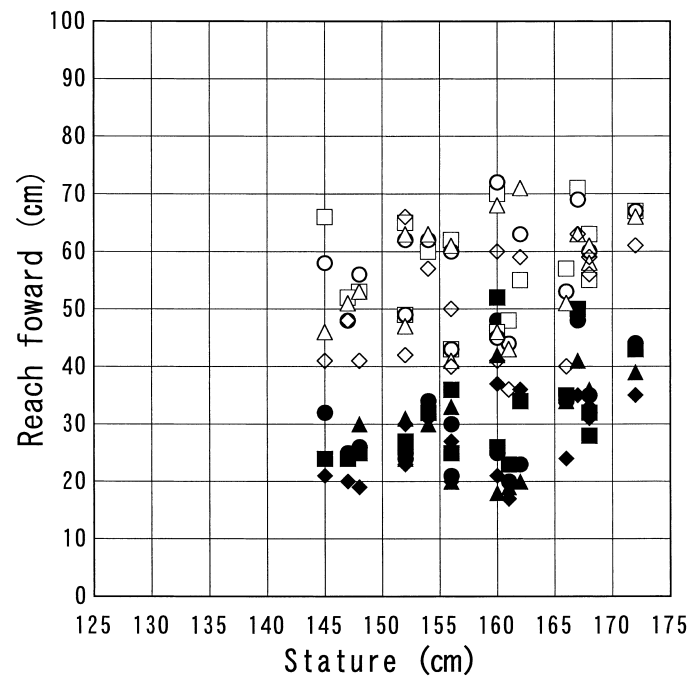

Fig. 4. Relationship between reach distance and stature in able-bodied elderly persons.

Legend: Closed symbols : comfortable reach, open symbols : a little strained reach.

Height of raised bed : $\square, \square: 60 \mathrm{~cm}, \boldsymbol{O}, \bigcirc: 70$ $\mathrm{cm}, \boldsymbol{\Delta}, \triangle: 80 \mathrm{~cm}, \diamond, \diamond: 90 \mathrm{~cm}$. 
身長と手が届く距離の関係という視点ではなく, 大多数の高齢者が使用可能なレイズドベッドの奥行 きという観点から，上記の結果をみてみると，楽に 手が届く距離はほぼ $20 \mathrm{~cm}$ から $50 \mathrm{~cm}$ の範囲となる。 しかしながら, 図右上に分布する記号口および○は, Table 1 に示した身長からも明らかなように男性被 験者のグループに属し，作業面高がそれぞれ $60 \mathrm{~cm}$ および70 cm であること, また, Fig. 3 からも明ら かなように，この高さを選んだ男性被験者は 1 名で あり，身長の比較的高い男性被験者にとって，これ らの高さは大きな前傾姿勢となり, 腰部への負担が 大きくなるものと予想される。したがって，これら の点を除くと, 楽な姿勢で手が届く距離は, $20 \mathrm{~cm}$ 〜 $40 \mathrm{~cm}$ の範囲にあるとみなすことができる。さら に，白抜きの記号が示すように，無理のない範囲で 努力すれば手が届く距離の下限が，身長によらずほ ぼ $40 \mathrm{~cm}$ となっている。これらのことから, 本研究 の事例では, 手が届く距離として $20 \mathrm{~cm} \sim 40 \mathrm{~cm}$ の範 囲をとっておけば，身長によらず，ほぼ全員が足腰 に負担が少なく楽な姿勢で作業が行えることにな る。

\subsection{3 疲労部位}

被験者からの聞き取り調查では，予想される疲労 部位は腰であるという回答が多く得られた。そのよ うに回答した被験者の割合は, レイズドベッドの高 さが $60 \mathrm{~cm}$ で $53 \%, 70 \mathrm{~cm}$ で $33 \%, 80 \mathrm{~cm}$ で14\%, 90 $\mathrm{cm}$ で $0 \%$ ような分布となった。

3.2.4 腰部椎間板圧迫力の推定値

腰部にどの程度の負荷が生じているかを調べるた め, 被験者が作業しやすい高さとして選んだレイズ ドベッドでの作業姿勢から, 腰部椎間板圧迫力の推 定值を求めたところ， $0.6 \mathrm{kN} \sim 1.0 \mathrm{kN}$ の值が得られ た。

\section{4. 実験 2 デイサービス施設における高齢者}

\section{1 実験方法}

実験実施日が冬季であったことから，被験者とな るこの施設への通所者の健康を配慮して, 施設内の 機能訓練室において実施した。

健常高齢者を対象にした実験で用いたレイズドべ ッドは，屋内での使用には大きすぎる。また，レイ ズドベッド内の土壤はセンター戒場のものを使用し たことから, 重量が過大となり移設が困難であった。 これらのことから, デイサービス施設では, レイズ ドベッドの高さおよび奥行きは同一としたが，間口 を90 cm とした。また, 高さは, 平均年齢が扔およ そ85歳であったこと, 実験に要する時間, 身体への
負荷等を考慮して，60，70，80および $90 \mathrm{~cm} の 4$ 種 類とした。材料は，スギ間伐材を使用し，断面を大 きくとることにより，耐力を向上させた。また，土 壤は市販の軽量なもの(タキイ種苗 花と野菜の土) を用いた。このほか, 室内での使用を考慮して, 側 面および底面からの水漏れを防ぐための工夫を取り 入れた。

測定項目は, 先の健常高齢者とほぼ同じであるが, 手が届く距離に関しては, 楽に手が届く距離のほか, 作業が行える限界の距離を求めることとした。健常 高齢者の実験では，「無理のない範囲で努力すれば できる」距離としたが, デイサービス施設では, こ の教示が伝わりにくかったことから，上記のような 条件で測定を行うことにした。

また，予備実験から，「楽な姿勢で手が届く距離」 については, 被験者が判断しやすい以下のような手 順をとることにした。(1)レイズドベッドの中央にパ ンジーの苗を植えてもらう, (2)11の作業を基準にし て, より楽と感じる位置に, 異なる苗を植えてもら う, (3)手が届き, 作業が行える最大の距離となる位 置にも植えてもらう, (4) 1 回の試行で楽に手が届く 距離や最大の距離を決めかねる場合は追加して植え てもらう。

被験者は，女性11名であり，身体特性および既往 症等は Table 1 のとおりである。なお，介助者の補 助や杖を必要とした被験者が若干名いたが, 車いす を用いた測定は行わなかった。

\section{2 実験結果}

\subsection{1 作業しやすい高さ}

作業しやすい高さは，11名中， 7 名が70 cm， 60 $\mathrm{cm}$ および $80 \mathrm{~cm}$ が各 1 名, $90 \mathrm{~cm}$ が 2 名という分布 となった。 $70 \mathrm{~cm}$ の高さを選択した被験者は, いず れも高さ $80 \mathrm{~cm}$ のものとの間に作業のしやすさの感 覚に差がなく, その中間の $75 \mathrm{~cm}$ があるとよいとの 訴えが聞き取り調查から得られた。

\subsection{2 手が届く距離}

手が届く距離と身長の関係を Fig. 5 に示した。黒 塗りの記号が楽に手が届く距離, 白抜きの記号が作 業が行える最大の距離である。白抜きの測点が黒の それより少ないのは Table 1 に示したような身体的 条件から測定が行えなかった被験者が数名いたため である。手が届く距離と身長には, 健常高齢者にみ られたような有意な相関関係はなかった。

楽に手が届く距離は, $10 \mathrm{~cm}$ から $45 \mathrm{~cm}$ の範囲に 分布している。また, 手が届く最大の距離の下限が $50 \mathrm{~cm}$ となっていることから，このデイサービス施 設の場合，身長打よび作業台の高さによらず $10 \mathrm{~cm}$ 


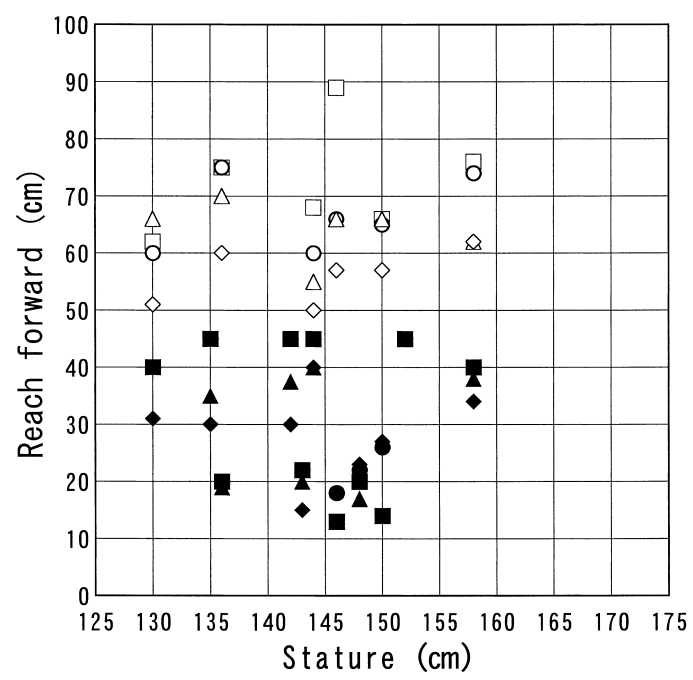

Fig. 5. Relationship between reach distance and stature in frail elderly persons.

Legend: Closed symbols : comfortable reach, open symbols : maximum reach.

Height of raised bed : refer to Fig. 4.

から $45 \mathrm{~cm}$ の範囲が作業しやすい奥行きと考えるこ とができる。

4.2.3 負荷部位

1 サイクルの実験に15分程度の時間を要したが, ほとんどの被験者から膝と腰に軽度の疲労感を覚え るとの訴えがあった。腰部椎間板圧迫力の推定值は, 被験者の多くがレイズドベッドに手や肘をつくなど ベッドで身体を支えながら作業していたことから， 求めることはできなかった。

\section{5. 考察}

\section{1 作業しやすい高さ}

高齢者身体機能および高齢者対応基盤整備に関す るデータベースを社団法人人間生活工学センター (HQL) が公開している6)。本研究に対応する立位に よる作業面高については，前者が作業台の上に置い た押しボタンの操作，後者が片手掠よび両手で物を 置く動作とノートパソコンの操作から適正高さを求 めている。片手動作はアルミ円筒（直径 $7 \mathrm{~cm}$, 高さ $28 \mathrm{~cm}$ ，重量 $0.5 \mathrm{~kg}$ ）を立てた下部を，両手による場 合はキャリアボックス（幅 $35 \mathrm{~cm} ，$ 奥行き $24 \mathrm{~cm}$ ，高 さ16 cm，重量 $1.5 \mathrm{~kg}$ ）の上部手がかり穴を，それぞ れ把持して台の上に置くという条件の下で計測が行 われている。ただし，キャリアボックスを台の上に 置く動作は台の高さと手の高さに違い $(15.5 \mathrm{~cm})$ が あり, 動作姿勢が本研究と異なるため, ここでは参
照しないことにした。なお，後者のデータベースは 前期高齢者（65歳〜 74歳）を被験者としている。本 研究における健常高齢者の大半は前期高齢者であ り，身長および体重などの平均的な身体特性は，上 記再データベースの対応するそれらと大きな差はみ られなかった。デイサービス施設における高齢者に ついても同様であった。

押しボタン操作における男性の場合，60歳〜 69歳 では $87.3 \mathrm{~cm}, 70$ 歳〜 79歳では $83.9 \mathrm{~cm}, 80$ 歳以上では $81.9 \mathrm{~cm}$ の高さが適正高の平均值となっている。女 性の対応する適正高は，それぞれ $79.6 \mathrm{~cm}, 80.0 \mathrm{~cm}$ および77.5 cm である。片手でアルミ円筒を置く動 作の場合, 男性が $90.4 \mathrm{~cm}$, 女性が $85.9 \mathrm{~cm}$, パソコ ン操作では，男性が $90.9 \mathrm{~cm}$ ，女性が $85.9 \mathrm{~cm}$ となっ ている。

以上の適正高は，被験者の内観報告をもとに計測 がなされているが，筋電図をもとに最も筋の活動度 の少ない点を求めた結果 ${ }^{7}$ によると, 成人男性の場 合, 最もよい高さとして $90 \mathrm{~cm}$ の值が得られている。 女性の場合は, 男性の值から $5 \mathrm{~cm}$ 低く見積もれば, 対応する数值を求めることができるとしている。た だし, 高齢者は, 若年層に比べて $5 \mathrm{~cm} \sim 10 \mathrm{~cm}$ ほど 低い高さの作業台を好む傾向があることを考慮する 必要がある ${ }^{6)}$

本研究において健常高齢者が選んだ使いやすいレ イズドベッドの高さとして, 男性では $85 \mathrm{~cm}$ および $90 \mathrm{~cm}$ ，女性では $75 \mathrm{~cm}$ および $80 \mathrm{~cm}$ の值が得られた が，作業が両手であること，苗を植えた後，土面を 軽く押さえることを条件としたことなどから，押し ボタン操作の結果にほぼ対応していると考えられ る。また，デイサービス施設における高齢者はすべ て女性であり，しかも80歳以上がほとんどであった ことから, 聞き取り調查から得られた $75 \mathrm{~cm}$ が作業 に適した高さと考えられる。

なお，健常高齢者が使用しているキッチンの高さ を調査したところ, $80 \mathrm{~cm}$ および $85 \mathrm{~cm}$ のもの ${ }^{8)}$ が 多く, 日常使い慣れた作業面の高さに一致する傾向 が見られた。また，立位作業面の高さは肘の高さを 基準にとることが多( ${ }^{9-11)}$ ことから，全被験者を対 象に，作業しやすい高さと肘頭下縁高（上腕を下垂 し，手掌を内側にして前腕を水平前方に曲げた姿勢 で，床面から肘頭下縁までの距離）の差の平均を求 めてみると, $19 \mathrm{~cm}$ という值が得られた。したがっ て，作業しやすいレイズドベッドの高さは，おおよ そ

时頭下縁高 $-20 \mathrm{~cm}$ 
デイサービス施設における高齢者の場合，被験者 の多くが，レイズドベッドに身体を寄りかからせた り，利き腕でない方の手や両肘をベッド前縁につく ことによって身体を支えながら作業していたことか ら, 上記のような関係を求めることはできなかった。

\section{2 手が届く距離}

適正高さにおける作業域に関する HQL の高齢者 身体機能データベースは，被験者の利き手側第 3 指 先端が届く距離を求めており, 楽に届く範囲は男女 ともおおよそ $40 \mathrm{~cm} \sim 60 \mathrm{~cm}$ であり，少し努力したと きは男性でおおよそ $55 \mathrm{~cm}$ 65 cm，女性でおおよそ $50 \mathrm{~cm} \sim 70 \mathrm{~cm}$ となっている。アルミ円筒を置く作業 の場合, 楽に届く距離は, 男性で $58.8 \mathrm{~cm}$, 女性で $55.2 \mathrm{~cm}$ ，少し努力したときの男性が $73.2 \mathrm{~cm}$ ，女性 が $68.5 \mathrm{~cm}$ となっている。

本研究で得られた楽に手が届く距離の上限值と少 し努力をすれば届く距離（あるいは最大）の下限值 とも, HQL のそれらよりも小さくなっている。こ れは，作業しやすい高さのところでも触れたような 作業の仕方の違いによるものと考えられる。

このほか, 本研究の結果とほぼ対応する報告 ${ }^{7)} も$ ある。すなわち，立位作業で奥行きを考える場合の 基準として, 高さが $80 \mathrm{~cm}$ のと, $25 \mathrm{~cm}$ までの距 離であれば楽に手が届き, 比較的楽に手が届く距離 は $25 \mathrm{~cm} \sim 50 \mathrm{~cm}$ であり， $50 \mathrm{~cm} \sim 80 \mathrm{~cm}$ になると手を 届かせるのに困難となるとする報告である。

本研究において，デイサービス施設における高齢 者の楽に手が届く距離の範囲が，健常高齢者よりも 大きくなった理由として，前項で述べたように，レ イズドベッドに手や両肘をつくなどベッドで身体を 支えながら作業を行う被験者が多くみられたことが 下限值が $10 \mathrm{~cm}$ となった原因と考えられる。一方, 上限が $45 \mathrm{~cm}$ となる原因は，この施設の被験者の多 くが身長が低く腰が曲がっていることから，健常高 歯者よりも肩の位置が低くなり, 特に上腕がレイズ ドベッド上面に対して平行に近い状態で作業を行う 傾向がみられたことによるものと考えられる。

これらのことから，高齢者を対象にしたレイズド ベッドの奥行きは $10 \mathrm{~cm} \sim 40 \mathrm{~cm}$ の範囲とするのが望 ましいと考えられる。

\section{3 腰部椎間板圧迫力}

作業時に負荷が予想される部位は, 健常高齢者の 場合には腰部であり, レイズドベッドが高くなるに したがって，その割合は減少した。すなわち，楽に 作業ができる高さで無理なく楽に手が届く距離とな るような姿勢がとれる場合には, 腰部の負荷も減少 するものと考えられる。
このような観点から, 各被験者の腰部椎間板にど の程度の圧迫力が生じているか推定值を算出してみ たところ， $0.6 \mathrm{kN} \sim 1.0 \mathrm{kN}$ の值が得られた。腰部椎 間板圧迫力の許容限界值として $3.4 \mathrm{kN}$ が利用される ことが多く，この值を超えると，約 $30 \%$ の人に腰痛 などの障害が発生する可能性があるとされる。また, 許容限界值は, 性・年齢に依存し, 男性より女性の 方が低く，加齢にともない低下する傾向がある。60 歳以上の高齢者の場合, 男性では $2.3 \mathrm{kN}$, 女性では 1.8 $\mathrm{kN}$ とされる4)。したがって，本研究で得られた上記 の值は, 許容範囲内にあるものと考えられる。以上 のことから，各被験者が選択した高さのレイズドベ ッドで，無理のない楽な作業姿勢を保持することが できれば，腰痛などの原因となる負荷を軽減できる 可能性が高くなるものと思われる。

\section{6. まと め}

園芸療法庭園等において使用されるレイズドベッ ドは, 足腰に負担が少なく楽な姿勢で各種の園芸作 業が行えるよう作業面となる床を高くした設備であ る。しかしながら, 既設のレイズドベッドの多くは, 園芸療法の歴史が浅いことから, 人間工学的な視点, すなわち人体寸法や動作寸法をもとに製作されてい ないのが実情である。また，レイズドベッドには， 維持・管理のし易さから，コンクリートやレンガ等 の素材が多くの施設で用いられている。

本研究では, 人との親和性の高い木材を用いて, 足腰に負担が少なく楽な立位姿勢で園芸作業が行え るレイズドベッドの高さと奥行きを，健常高齢者お よびデイサービス施設に通所している何らかの障害 を有する高齢者を対象に測定した。また，レイズド ベッドの製作も園芸療法の一環とみなすことができ ることから，療法対象者および介護者等が容易に製 作できるように材料や構造に工夫を取り入れた。

得られた結果は以下のとおりである。

(1)作業しやすい高さは, 健常高齢者では男女にみら れた身長差の影響を受け，男性は85 cm および 90 $\mathrm{cm}$, 女性は $75 \mathrm{~cm}$ および $80 \mathrm{~cm}$ を選択した被験者が 多かった。また，作業しやすいレイズドベッドのお およその高さは, 男女を問わず，时頭下縁高を基準 に, 式(1) から求めることができる。デイサービス 施設通所者では， $70 \mathrm{~cm}$ を選択した被験者が多かっ たが, $80 \mathrm{~cm}$ のものと感覚的には差はなく, むしろ それらの中間である75 cm がよいとの訴えが多かっ た。

(2)作業しやすい奥行きは，健常高齢者では，男女お よび身長に関係なく $20 \mathrm{~cm} \sim 40 \mathrm{~cm}$ の範囲であった。 
一方，デイサービス施設における高齢者のそれは 10 $\mathrm{cm} \sim 45 \mathrm{~cm}$ であった。これらのことから，高齢者を 対象にしたレイズドベッドの奥行きは $10 \mathrm{~cm} \sim 40 \mathrm{~cm}$ の範囲とするのが望ましいと考えられる。

(3)身体への負荷部位として訴えのあった箇所は，健 常高齢者の場合は腰であり，高さが低くなるにとも なってその割合が増加した。デイサービス施設にお いては, 膝および腰に軽度の度労感があるとの訴え が多かった。

\section{謝辞}

本研究の一部は, 平成16年度千葉県新産業ソーイ ング事業助成金によって行われた。本事業の計画揖 よび実施に際して, 島田建設株式会社 島田 隆氏 および山本英文氏，JFEテクノリサーチ株式会社 加藤弘之氏, 田原紘一氏および中原久直氏から, 支 援と有益な助言をいただいた。

本研究の実験を行うに当たり, 本センターボラン ティア団体千緑会および園芸デイサービスなりたの 職員の方々にご協力いただいた。また，千葉工業大 学助教授上野義雪氏には, 人間工学の視点から懇切 なご指導をいただいた。

これらの方々に，この場を借りて深甚なる謝意を 表する。

\section{文献}

1）山根 寛：“園芸リハビリテーション 園芸療
法の基礎と事例”, 医歯薬出版株式会社, 東京, 2003, pp. 1-7.

2) 高江洲義英：人間 - 植物関倸学会 $4(1 \cdot 2), 1-2$ (2005).

3）徳田哲男：“四説エルゴノミクス”, 野呂影勇他 編, 日本規格協会, 東京, 1990, pp. 324-328.

4）瀬尾明彦：筋骨格系障害予防のための作業負 担ソフト Bless Pro, 人間工学と産業保険のホー ムページ, http://www.ergooh.com/.

5）ベネデイック,ビラース：“医系の物理一医学 および生物学より例をとった物理学ー第 1 巻 a 力学上”, 井上 章監修, 吉岡書店, 京都, 1992, pp. 153-169.

6）社団法人人間生活工学センター：人間特性デ ータベー ス, http://www.hql.jp/database/index. html.

7）小原二郎, 内田祥哉, 宇野英隆：“建築 - 室内 人間工学”, 鹿島出版, 東京, 1975, pp. 166-168.

8）日本工業規格 JIS A 0017キッチン設備の寸法, 日本規格協会, 東京, 1998, pp. 1-6.

9）人間工学部会：“建築設計資料集成 3 単位空間 I ”, 日本建築学会編, 丸善, 東京, 1980, p. 4.

10）戸上英徳：“図説エルゴノミクス”, 野呂影勇他 編, 日本規格協会, 東京, 1990, pp. 78-79.

11) Paul, J. A., Frings-Dresen, M. H. W., Sallé, H. J. A., Rozendal, R. H. : Applied Ergonomics, 26 (2), 129-133 (1995). 